\title{
Economic Contribution of Tourism Industry in Bangladesh: At a Glance
}

Abstract- Tourism is a dynamic and one of the most profitable sectors for the world economy as well as for many developing countries like Bangladesh. Bangladesh has so many natural, cultural, historical, archeological, religious and man-made tourist destinations. By visiting this country one can get the opportunity to know about the tribal people, their unique culture, traditions, food habit, wildlife of various species and also can enjoy diversified tourism-related activities like water skiing, river cruising, hiking, rowing, yachting, kidding, sea bathing etc. Tourism industry is considered as a growing industry for many developing countries. It plays a significant role directly and indirectly in the GDP growth rate of Bangladesh by creating new employment opportunities for both male and female, alleviating poverty, enhancing local community participation, earning foreign currency via foreign tourists, improving the economic standards of locals, making people economically and socially stable. This research is carried out based on the qualitative approach.

Keywords: tourism, economic contribution, tourism growth, SWOT analysis.

GJMBR-F Classification: JEL Code: M10

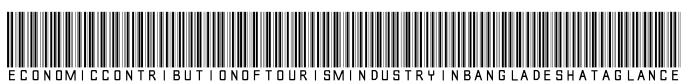

Strictly as per the compliance and regulations of:

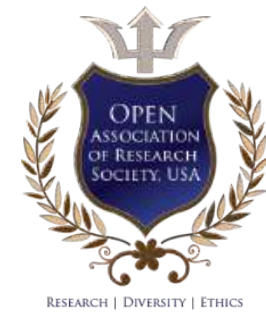

(C) 2020. Shelamony Hafsa. This is a research/review paper, distributed under the terms of the Creative Commons AttributionNoncommercial 3.0 Unported License http://creativecommons.org/licenses/by-nc/3.0/), permitting all non-commercial use, distribution, and reproduction in any medium, provided the original work is properly cited. 


\title{
Economic Contribution of Tourism Industry in Bangladesh: At a Glance
}

\author{
Shelamony Hafsa
}

Abstract- Tourism is a dynamic and one of the most profitable sectors for the world economy as well as for many developing countries like Bangladesh. Bangladesh has so many natural, cultural, historical, archeological, religious and man-made tourist destinations. By visiting this country one can get the opportunity to know about the tribal people, their unique culture, traditions, food habit, wildlife of various species and also can enjoy diversified tourism-related activities like water skiing, river cruising, hiking, rowing, yachting, kidding, sea bathing etc. Tourism industry is considered as a growing industry for many developing countries. It plays a significant role directly and indirectly in the GDP growth rate of Bangladesh by creating new employment opportunities for both male and female, alleviating poverty, enhancing local community participation, earning foreign currency via foreign tourists, improving the economic standards of locals, making people economically and socially stable. This research is carried out based on the qualitative approach. Secondary data sources are generally used for collecting and analyzing necessary information. The basic objective of this paper is to show the direct and indirect economic contribution of the tourism industry in the economy of Bangladesh. Here the author also tries to find out the tourism growth rate at different years, the number of tourists arrivals, SWOT analysis, focusing on the economic prospects in comparison to other countries and tries to suggest some recommendations for the development of tourism industry in Bangladesh. Although there exit many threats and challenges for ensuring the development of tourism industry, it has been believed that proper planning, policy development and necessary steps regarding tourism industry could help to turn Bangladesh as one of the best promising tourist destinations by using the massive strengths and opportunities for the flourishment of this sector.

Keywords: tourism, economic contribution, tourism growth, SWOT analysis.

\section{InTRODUCTION}

T ravel and tourism are one of the fastest-growing industries (Dwyer and Spurr, 2010) and day by day; it is contributing more and more to the world economy (WTTC, 2014). In recent years, this emerging industry has started to contribute significantly to the national economy of Bangladesh (WTTC, 2017). Tourism, which is a rapidly growing sector in the world, is expected to contribute to the MDGs (Millennium Development Goals)in developing countries and their sustainable future since it has the ability to generate jobs, income, and hard currency (Sirakaya, Jamal \&

Author: Lecturer, Department of International Tourism and Hospitality Management, School of Business, Primeasia University, Dhaka, Bangladesh.e-mail: Shelamonyhafsa@gmail.com
Choi, 2001). The total contribution of Travel and Tourism to the national GDP of Bangladesh was BDT 809.6bn ( $4.7 \%$ of the total GDP) and was forecasted to rise by $6.4 \%$ per annum to BDT 1,596.0bn (5\% of the total GDP) in 2026 (WTTC, 2015). However, to keep the growth rate as forecasted, Bangladesh needs to focus on new forms of tourism to attract both international and domestic tourists as the typical natural, cultural, and historical attractions are facing fierce competition in the global tourism market. UN World Tourism Organization (UNWTO, undated) reported that the international tourism annual arrival rate increased by $6.5 \%$ (2005) with 806 million travelers, growing from 25 million in 1950. While tourism can also benefit multiple sectors, it touches on a broad range of issues such as the economy, environment, and society (Tosun 2000). Tourism supports the socio-economic development of rural areas around the world by diversifying rural economies, providing linkages between different economic sectors, generating employment, increasing the value of the physical environment, and local culture (Sharpley and Sharpley, 1997; Telfer, 2002). Updated and proper planning is essential to the flourish the tourism industry by minimizing the weakness and negative impacts.

\section{il. Literature Review}

The tourism industry plays an important role in the economy of both developing and developed countries. Tourism is one of the most profitable sectors in Bangladesh (Elena et al., 2012). Tourism means the short-term movement of people outside the usual working and living places. There exist a large number of definitions regarding the words "tourism." Guyer Feuler gave the first definition of tourism in 1905. Guyer Feuler (1905)defined tourism as "A collection of activities, services, and industries which deliver a travel experience comprising transportation, accommodation, eating and drinking establishments, retail shops and other hospitality services provided for individuals or groups traveling away from home"(Alex Delmonte). Different scholars and organizations provided different definitions of tourism from various perspectives. UNWTO defined tourism where were mentioned that "Tourism comprises the activities of a person traveling to and staying in the places outside their usual environment for not more than one consecutive year for leisure, business, and other purposes" (UNWTO report, 1987). International 
Association of Scientific Experts on Tourism (AIEST) has adopted the definition given by Swiss Professors Hunziker and Kraft. AIEST explained tourism as the sum of the phenomena on which travelers travel to any destination as non-residence, and they don't be permanent residence and not connect with any earning activities here. Tourism development is considered as a set of economic activities which contribute to the welfare and economic development of tourist destinations.

According to the opinion of Faruq and Bhuiyan (2003), tourism nowadays is one of the main sources of earning foreign exchange for many countries. And Bangladesh could be considered as a developing country. Tourism influences the social, cultural, and environmental surroundings of the origins and the destination countries of the tourists (P. Basu, 2004). As Ashley and Roe (1998) noted: "Tourism can bring an array of advantages, both for rural communities and for the economic growth." Effective management should entail balancing conflicting ecological, social, and environmental pressures. (Goodwin et al. 1998). Tourism creates job opportunities for the local people as well as contributes to the national GDP of a particular country.

The tourism industry is not only growing in Bangladesh, but also becomes as a vital sector in the world economy (Blanke and Chiesa, 2006). According to the opinion of Yilmez(2008), it can be said that the tourism industry is one of the fastest-growing sectors of the global economy; tourism consists of many small and medium-size enterprises that try to be successful in the extremely competitive and rapidly changing business environment. And Bangladesh is famous for its scenic beauty (Ali and Mobasher, 2004). Foreign tourists interested to travel here due to its natural beauty, diversifies the culture, and hospitality of locals. So, Bangladesh is a country of Asian region holding high potentiality of tourism (Islam and Islam, 2006), which will contribute directly and indirectly in the GDP of Bangladesh.

According to different articles and reports of WTTC and WTO, the number of tourist arrivals (both domestic and international) has increased dramatically. According to Masud (2015), Bangladesh has a positive trend in comings and earnings from tourism, which can be improved at a significant level if the country can undertake necessary promotional measures and appropriately maintain the resources of that area. Sandip (2014) mentioned in his article that the development of the tourism service industry would accelerate our economic growth. Besides that, Red wan (2014) tried to highlight the importance of tourism in Bangladesh, along with its benefits in socio-economic development. It contributes not only in the expansion of GDP but also afford in generating employment opportunity both for male and female, earning foreign currency, developing infrastructure, alleviation of poverty etc. Considering this, Shamsuddhoha and Chowdhury commented that there are lots of opportunities to earn overseas and local revenue from the tourism sector. Ferdoush and Faisal (2014) also commended the significance of tourism in different view like economic, social, cultural, political, etc.

\section{ili. The Methodology of the Study}

The methodology outlines the data collection and data analysis process. This research is carried out by using the qualitative research approach. Qualitative methods have become increasingly appropriate to researchers of tourism as they begin to explore personal feelings, perceptions, and attitudes, particularly of host communities, and the impact of tourism on them (Walle, 1997: 534). Exploratory analysis is done for this study and data are collected from secondary data sources. Secondary data sources mean those data which are composed by others for their purposes. Various reports, documents, census reports, journals, articles, books, annual reports, literature, market studies, electronically stored information were also reviewed.

\section{Objectives of the Study}

\section{a) Primary objectives}

The Primary objective of this study is to identify the economic contribution of the tourism industry in Bangladesh.

\section{b) Secondary objectives}

- To understand the tourism growth in Bangladesh.

- To hear about the strengths, weaknesses, opportunities, and threats of tourism industry of Bangladesh.

- To explore the major tourist's destinations/attractions in Bangladesh.

- To know the present status of tourism in Bangladesh in comparison with other countries.

- To find out some recommendations that will help to increase the growth of the tourism industry in Bangladesh.

\section{Tourism in Bangladesh}

People can travel for different reasons like medical purposes, business, education, leisure, pleasure, religious purposes, and others. As Bangladesh is a city full of natural, cultural, archeological, religious, and artificial tourist places, it can easily attract so many domestic as well as foreign tourists. The contribution of travel and tourism in the GDP of Bangladesh is also increasing. The tourism economy has expanded consistently over the last few decades, with global international arrivals reaching one billion annually in 2012 (UNWTO, 2012). Nowadays, tourism businesses become the top focus around the world. Hall and Boyd (2005) claim that many peripheral destinations have limited potential to develop tourism 
due to a lack of access to transport networks, information, political power, and capital. Moreover, the small-scale supply leverages few resources to compete in major markets, making internationalization difficult (The Agndal \& Elbe, 2007).

\section{Vi. Major Tourist Destinations in BANGLADESH}

Visitor's attractions are the primary components of the tourism system and one of the major motivational factors behind the decision to visit any destination. Attraction is "the power or act of attracting, or a desirable or pleasant quality or thing" (The New Lexicon, 1991, p. 61). One of the psychologist P. Pearce (1991, p. 46) formulated the simplest definition of attraction, who described attractions as "a named site with a specific human or natural feature which is the focus of visitor and management attention." Attractions are the key components that attract or motivate visitors to travel in any particular area.

\begin{tabular}{|c|c|l|}
\hline $\begin{array}{c}\text { Serial } \\
\text { No. }\end{array}$ & Category & \multicolumn{1}{c|}{ Name of the Tourist destination } \\
\hline 1. & $\begin{array}{c}\text { Beaches and } \\
\text { Island }\end{array}$ & $\begin{array}{l}\text { Cox's Bazar Sea beach, Kuakata Sea-beach, Potenga Sea-beach,Saint- } \\
\text { martin Island, Nihjum Dip, Parki sea beach, Kotka sea beach etc. }\end{array}$ \\
\hline 2. & $\begin{array}{c}\text { Hills and } \\
\text { waterfalls }\end{array}$ & $\begin{array}{l}\text { Bandarban hill tracts :Nilgiri, Nilachal, Chimbuk hills, Keoradadong, Tajigdon } \\
\text { and many others, Khagrachori Hill tracts, Shuvolong waterfall, Madhobkundu } \\
\text { Waterfall, Hum hum waterfall etc. }\end{array}$ \\
\hline 3. & Forests & Sundarbans, Ratargul swamp forest, Madhupur and vowal gore \\
\hline 4. & Religious sites & $\begin{array}{l}\text { Golden temple, Kantojiu Temple, Dhakeshwari Temple, Sixty Dome Mosque, } \\
\text { Start Mosque, Hazrat Shahjalal Mazar, }\end{array}$ \\
\hline 5. & $\begin{array}{c}\text { Historical and } \\
\text { Archeological } \\
\text { sites }\end{array}$ & $\begin{array}{l}\text { Lalbagh Fort, Curzon Hall, Somapura Mahavihara, Jatiyo Sangshad Bhaban, } \\
\text { Suhrawardy Udyan, Ahshan Monjil, Aporajeo Banglaetc }\end{array}$ \\
\hline 6. & $\begin{array}{c}\text { Dark tourist } \\
\text { spots }\end{array}$ & Central Shahid Minar, Jatio Smriti Soudho, National poet's graveyard. \\
\hline 7. & Lakes & Foy's Lake, Madhobpur lake, Boga lake, Kaptai Lake, Dhanmondi Lake \\
\hline 8. & $\begin{array}{c}\text { Man-made } \\
\text { tourist spots }\end{array}$ & Heritage Park, Dulahazra Safari Park, Butterfly Park, Foy's Lake etc. \\
\hline 9. & Other attractions & Ramna Park, National Zoo, Jamuna Bridge etc. \\
\hline
\end{tabular}

a) Unesco Recognized World Heritage Site in Bangladesh

Three places of Bangladesh have been recognized by UNESCO as world heritage sites which are:

\begin{tabular}{|c|c|c|c|}
\hline Serial No. & Name of the place & Recognition year & Category \\
\hline 1. & The Sundarbans & Natural & 1997 \\
\hline 2. & Ruins of the Buddhist Vihara at paharpur & Cultural & 1985 \\
\hline 3. & Historic Mosque city of Bagerhat & Cultural & 1985 \\
\hline
\end{tabular}

Source: Whc.UNESCO.Org

Vil. Economic Contribution of

TOURISM AND TOURISM GROWTH IN BANGLADESH

Bangladesh tourism sector has experienced growth in recent years, particularly in the last decade. However, the growth pattern has been erratic implying unstructured development and perhaps also the lack of proper planning from the government. The number of tourists has grown from 113.2 million in 1995 to 303.4 million in 2010 with years in between experiencing higher tourist traffic. (WTTC 2011)). The decadal growth rate shows that the growth in number of tourists has declined in the 2001-10 period in comparison to 199100 period. Falling tourist arrival is a ominous sign for the industry and demands further investigation by the authorities to identify the reasons behind this. Some of the reasons which are frequently pointed out by tourists for not visiting Bangladesh are the lack of adequate facilities in terms of accommodation as well as transport linkages, and the political instability/security issue. According to the WTTC report (2015), the economic contributions of the travel and tourism sectors are given below: 
Table 1: Economic contribution of travel and tourism (nominal prices)

\begin{tabular}{|c|c|c|c|c|c|c|c|c|}
\hline $\begin{array}{c}\text { Bangladesh (BDTbn, } \\
\text { nominal prices) }\end{array}$ & $\mathbf{2 0 0 9}$ & $\mathbf{2 0 1 0}$ & $\mathbf{2 0 1 1}$ & $\mathbf{2 0 1 2}$ & $\mathbf{2 0 1 3}$ & $\mathbf{2 0 1 4}$ & $\mathbf{2 0 1 5}$ & $\mathbf{2 0 2 5 F}$ \\
\hline Visitor exports & 5.5 & 6.2 & 6.7 & 7.7 & 9.0 & 10.2 & 11.3 & 31.7 \\
\hline Domestic expenditure & 270.0 & 302.3 & 345.6 & 389.1 & 433.5 & 488.7 & 549.0 & 1578.3 \\
\hline Internal tourism consumption & 275.5 & 308.6 & 352.3 & 396.7 & 442.6 & 499.0 & 580.3 & 1610.0 \\
\hline Purchases by tourism provider & -110.3 & -125.3 & -147.0 & -165.3 & -180.9 & -202.4 & -227.2 & -636.2 \\
\hline $\begin{array}{c}\text { Direct contribution of travel and } \\
\text { tourism in GDP }\end{array}$ & 165.2 & 183.3 & 205.3 & 231.5 & 261.7 & 296.6 & 333.1 & 973.8 \\
\hline Capital Investment & 34.8 & 39.5 & 45.4 & 52.3 & 56.8 & 60.9 & 66.3 & 227.1 \\
\hline $\begin{array}{c}\text { Total contribution of travel and } \\
\text { tourism to employment }\end{array}$ & 1919.8 & 1884.1 & 1848.8 & 1896.1 & 1945.2 & 1984.1 & 2028.5 & 2492.4 \\
\hline
\end{tabular}

Source: WTTC report, 2015

Table 2: Economic contribution of travel and tourism growth rate (percentage)

\begin{tabular}{|c|c|c|c|c|c|c|c|c|}
\hline Bangladesh Growth (\%) & $\mathbf{2 0 0 9}$ & $\mathbf{2 0 1 0}$ & $\mathbf{2 0 1 1}$ & $\mathbf{2 0 1 2}$ & $\mathbf{2 0 1 3}$ & $\mathbf{2 0 1 4}$ & $\mathbf{2 0 1 5}$ & $\mathbf{2 0 2 5 \mathrm { F }}$ \\
\hline Visitor exports & 40.3 & 5.6 & 0.0 & 6.1 & 11.0 & 5.8 & 3.7 & 5.7 \\
\hline Domestic expenditure & 0.4 & 3.8 & 5.8 & 5.1 & 4.9 & 5.3 & 5.9 & 5.9 \\
\hline Internal tourism consumption & 0.9 & 3.8 & 5.7 & 5.1 & 5.1 & 5.4 & 5.9 & 5.9 \\
\hline Purchases by tourism provider & 6.8 & 5.3 & 8.6 & 4.9 & 3.1 & 4.5 & 5.8 & 5.6 \\
\hline $\begin{array}{c}\text { Direct contribution of travel and } \\
\text { tourism in GDP }\end{array}$ & -2.7 & 2.9 & 3.6 & 5.2 & 6.5 & 5.9 & 5.9 & 6.1 \\
\hline Capital Investment & 3.2 & 5.3 & 6.3 & 7.4 & 2.2 & 0.2 & 2.7 & 7.8 \\
\hline $\begin{array}{c}\text { Total contribution of travel and } \\
\text { tourism to employment }\end{array}$ & -8.5 & -1.9 & -1.9 & 2.6 & 2.6 & 2.0 & 2.2 & 2.1 \\
\hline
\end{tabular}

Source: WTTC report, 2015

a) Visitor Exports (BDT Billion and \%)

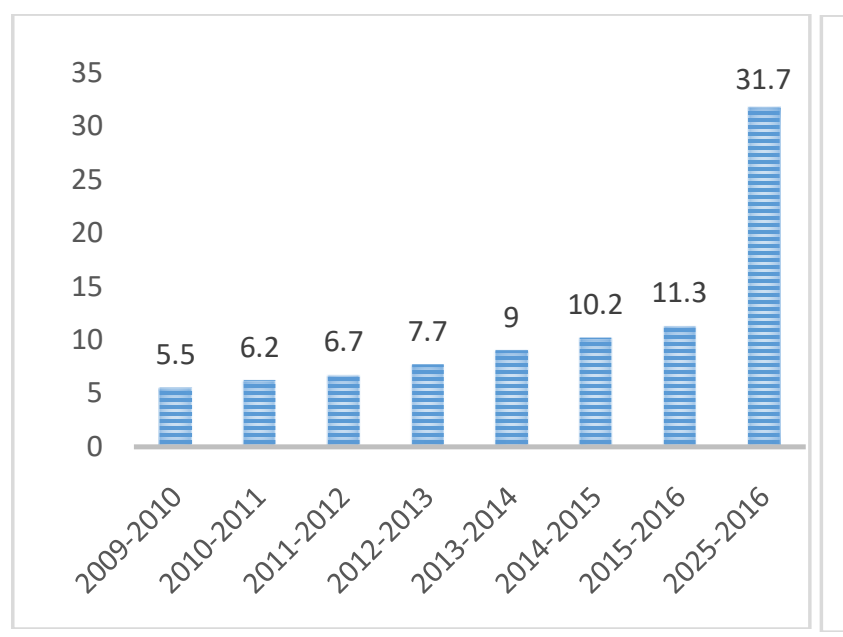

Figure 2: Visitor exports (BDT billion)

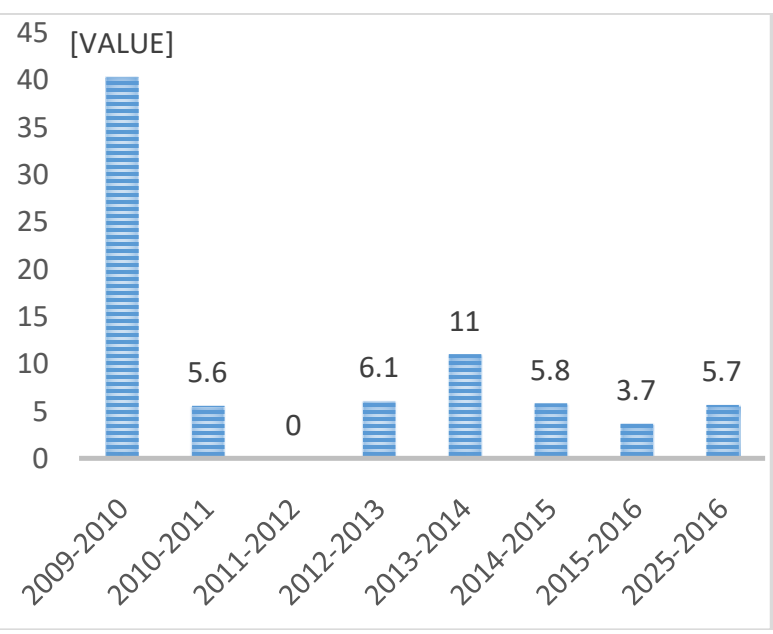

Figure 3: Visitor Export (\%)

According to the first figure, we can say that in Bangladesh visitor export is consistently increasing year by year. In 2009-10, the number of visitor export was 5.5 billion taka and in 2015-16 reached 11.3 billion taka which is almost double from the starting year, and it is expected to reach 31.7 billion taka in 2025-2026 sessions and which is triple from the present year. On the other hand, the second figure shows the visitor export growth, which is not consistent compared to the previous year. There were massive ups and downs. 
b) Capital Investment (BDT Billion and \%)

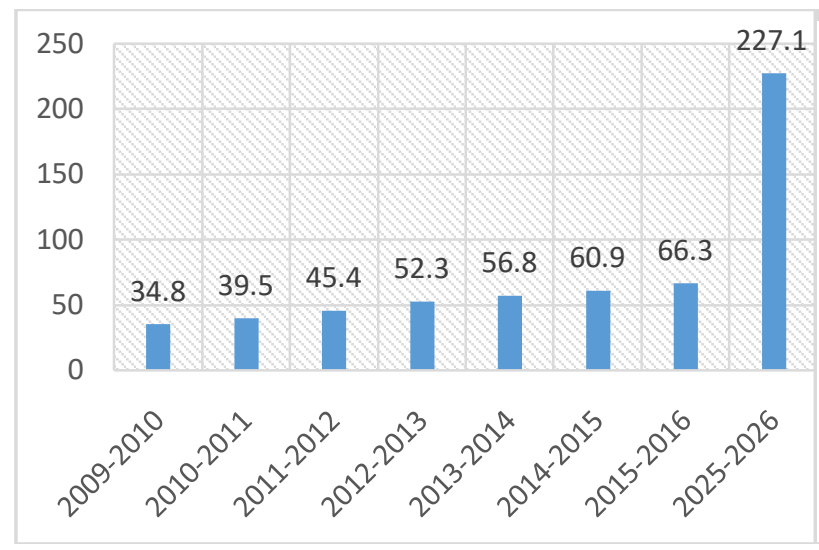

Figure 4: Capital Investment (BDT Billion)

According to first figure, we can say that in Bangladesh visitor export is consistently increasing year by year. In 2009-10, the number of capital investments was 34.8 billion taka and in 2015-16 reached to 66.3 billion taka which is almost double from the starting year, and it is expected to reach 227.1 billion taka in

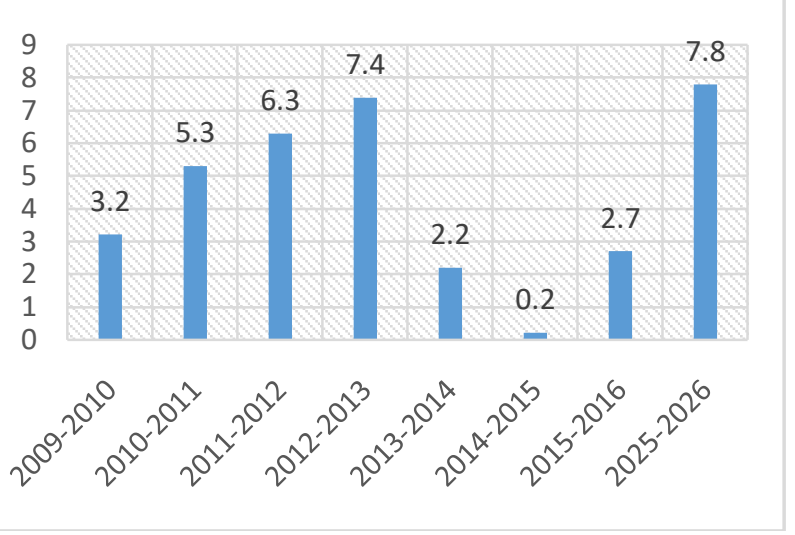

Figure 5: Capital Investment (\%)

2025-2026 sessions and which is triple from the present year. On the other hand, the second figure shows capital investment growth, which is not consistent compare to previous year. There are vast ups and downs.

c) The direct contribution of travel and tourism in GDP (BDT Billion and \%)

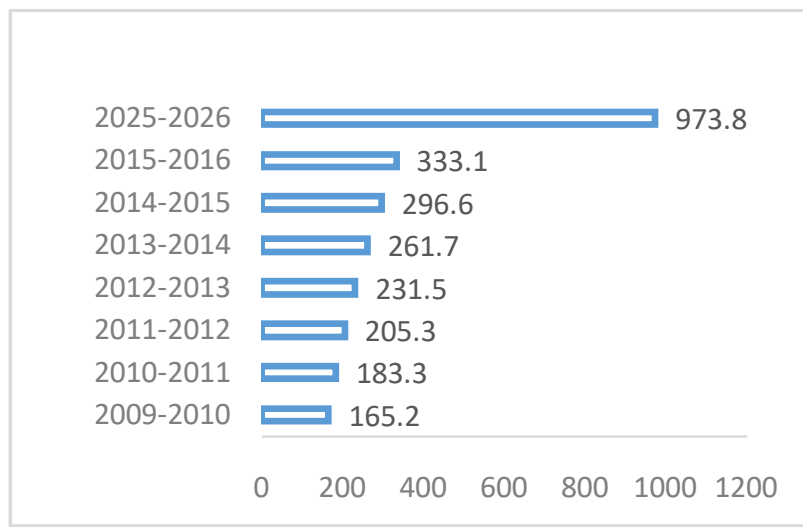

Figure 6: Direct Contribution to GCP (BDT Billion)

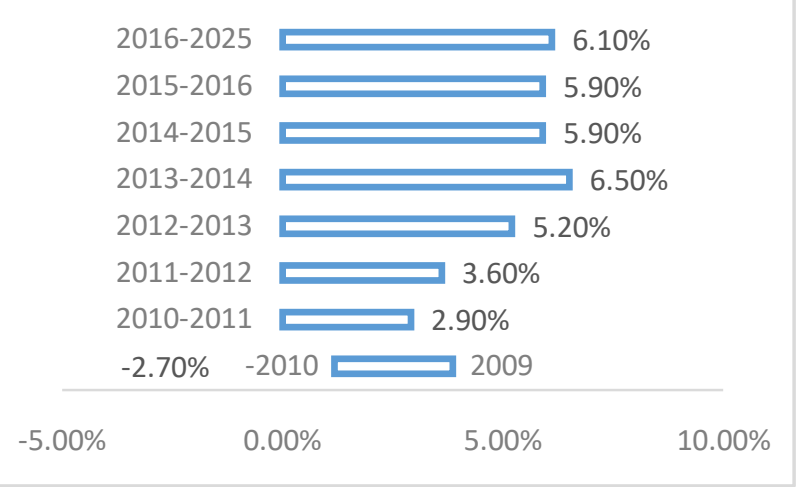

Figure 7: Direct Contribution to GDP (\%)

According to the first figure, we can say that in Bangladesh the direct contribution of travel and tourism is consistently increasing year by year. In 2009-10, it was 165.2 billion taka, and in 2015-16, it was 333.1 billion taka which is almost double and it is expected that it will reach 973.8 billion taka in 2025-2026 session. On the other hand, the second figure shows that the direct contribution to GDP is not consistent. There are vast ups and downs. In 2009-10, it was negative. 


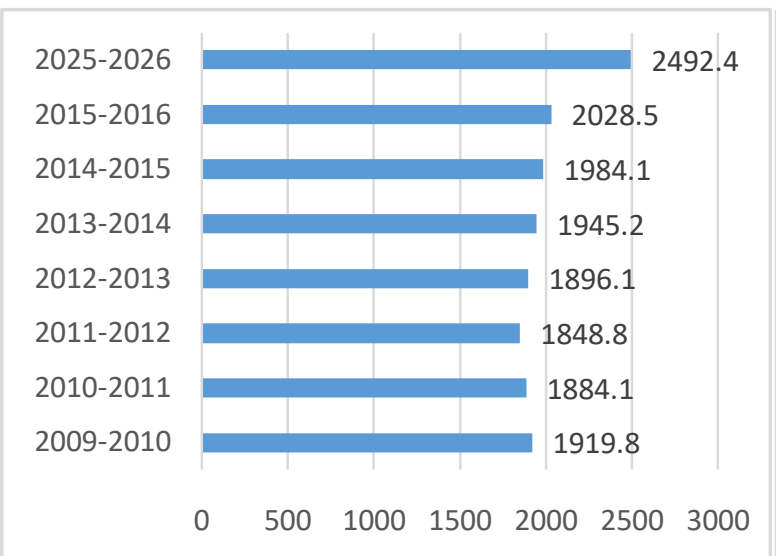

Figure 8: Contribution to Employment

From figure one, it can be said that the growth of contribution to employment was lightly decreasing, and then it was gradually increasing. In 2009-2010, it was 1919.8 billion and in 2015-16, it was 2028.5. And it is estimated that it will be 2492.4 in 2025-2026. On the other hand, the second figure shows that the percentage of contribution becoming positive day by day. In 2009-10, it was negative $-8.50 \%$ although in 2015-16, it was $2.20 \%$.

\section{a) The total contribution of travel and tourism to employment (BDT Billion and \%)}

Table 3: Comparison (2015)

\begin{tabular}{|c|c|c|c|c|c|c|}
\hline Growth (\%) & Bangladesh & India & Nepal & Indonesia & Thailand & Malaysia \\
\hline Visitor exports & 3.7 & 0.1 & 1.1 & 5.5 & 5.0 & 5.8 \\
\hline Domestic expenditure & 5.9 & 10.3 & 8.5 & 6.4 & 3.7 & 5.5 \\
\hline Internal tourism consumption & 5.9 & 8.4 & 5.4 & 6.2 & 4.7 & 5.7 \\
\hline Purchases by tourism provider & 5.8 & 8.6 & 5.5 & 6.3 & 5.1 & 5.7 \\
\hline $\begin{array}{c}\text { Direct contribution of travel and } \\
\text { tourism in GDP }\end{array}$ & 5.9 & 8.0 & 5.4 & 6.0 & 4.3 & 5.6 \\
\hline Capital Investment & 2.7 & 7.5 & 12.0 & 5.7 & 8.0 & 5.3 \\
\hline $\begin{array}{c}\text { Total contribution of travel and } \\
\text { tourism to employment }\end{array}$ & 2.2 & 1.7 & 4.4 & 3.3 & 2.0 & 3.1 \\
\hline
\end{tabular}

Table 4: Comparison (2025)

Source: WTTCreport, 2015

\begin{tabular}{|c|c|c|c|c|c|c|}
\hline Growth (\%) & Bangladesh & India & Nepal & Indonesia & Thailand & Malaysia \\
\hline Visitor exports & 5.7 & 6.3 & 6.0 & 5.5 & 7.5 & 3.5 \\
\hline Domestic expenditure & 5.9 & 7.2 & 3.2 & 5.3 & 3.3 & 4.7 \\
\hline Internal tourism consumption & 5.9 & 7.0 & 4.4 & 5.4 & 6.6 & 4.0 \\
\hline Purchases by tourism provider & 5.6 & 6.9 & 4.4 & 5.3 & 6.5 & 4.0 \\
\hline $\begin{array}{c}\text { Direct contribution of travel and } \\
\text { tourism in GDP }\end{array}$ & 6.1 & 7.2 & 4.4 & 5.3 & 6.7 & 4.1 \\
\hline Capital Investment & 7.8 & 6.5 & 5.2 & 7.1 & 6.6 & 6.3 \\
\hline $\begin{array}{c}\text { Total contribution of travel and } \\
\text { tourism to employment }\end{array}$ & 2.1 & 2.0 & 3.1 & 1.8 & 4.6 & 3.2 \\
\hline
\end{tabular}

Source: WTTC report, 2015 
The first table compares the economic contribution and growth of the travel and tourism industry among different countries in the year 2015-16. Whether the second table shows the comparison of the economic contribution of travel and tourism, which is forecasted for the year 2025-2026. The following chart shows the individual variable's comparisons among different countries:

b) Visitor exports

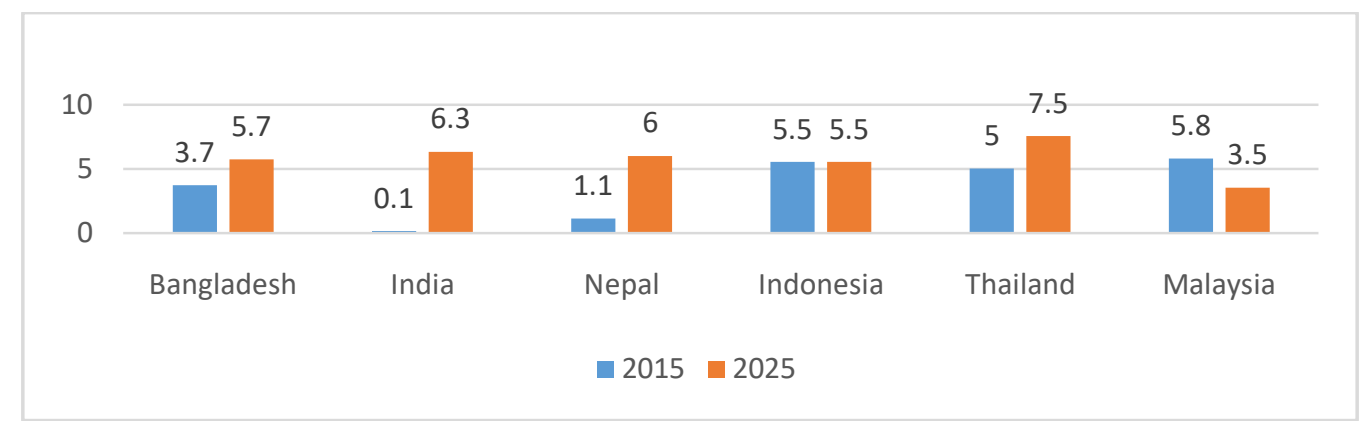

Figure 10: Comparision of visitor exports (\%) among different countries

Visitor export is the spending within a country by international tourists for leisure and business travel. From the figure, it can be said that visitor exports of Bangladesh will be increased in 2025 than in 2015.

c) Capital investment

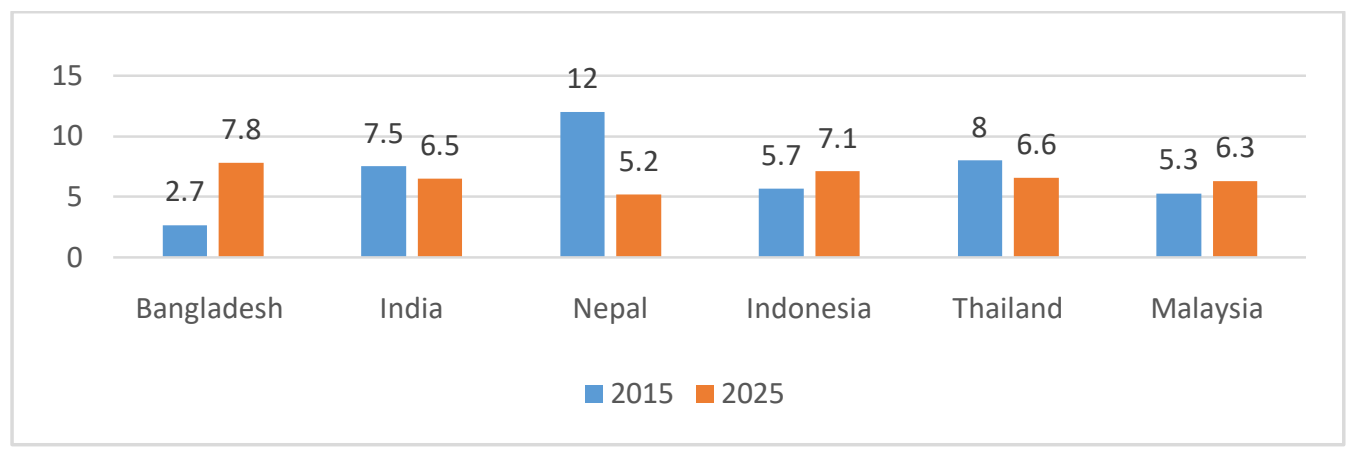

Figure 11: Comparision of capital Investment (\%) among different countries

The figure shows that Nepal invests more in the travel and tourism industry in the year 2015-16 comparing to other countries. And capital investment in travel and tourism of Bangladesh is relatively low than other countries in the year 2015-16. But it is forecasted that Bangladesh will invest more compared to other countries in the travel and tourism industry in the year 2025-26. Because the travel and tourism industry is a growing industry in Bangladesh and it has high potentials here.
From among these countries, Malaysia gains more visitor exports in 2015, and from the forecasted value, Thailand will expand more from visitor exports in 2025. 
d) Direct contribution of trave/ and tourism in GDP

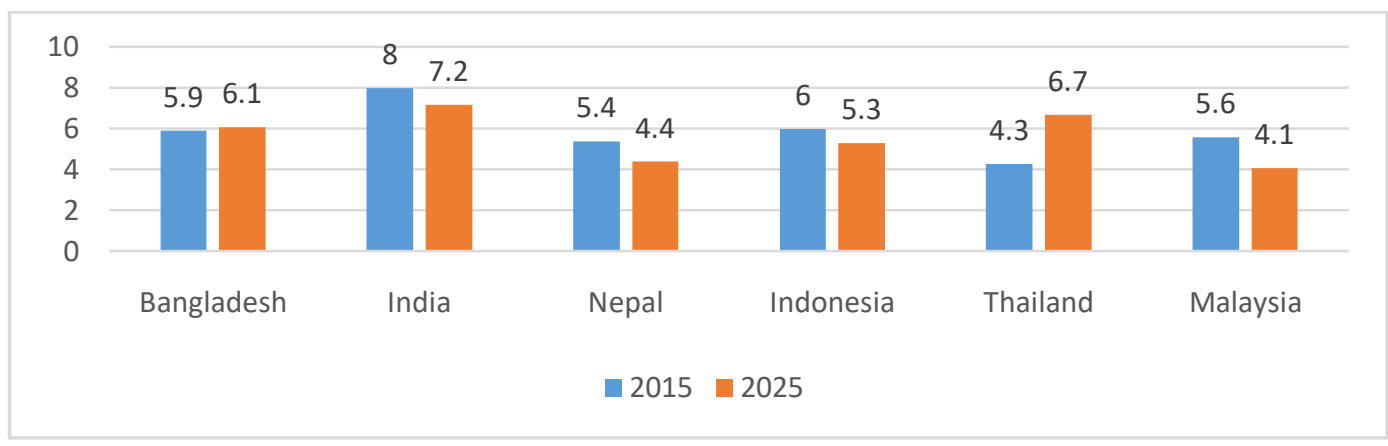

Figure 12: Direct contribution of travel and tourism in GDP (\%)

The above figure shows the direct role of travel and tourism in GDP among different countries. Compared to others, it can be said that direct contribution of the travel and tourism in GDP is high in India from others. Among these countries, contribution

e) Total contribution of travel and tourism to employment of the travel and tourism industry in Bangladesh's GDP is relatively good. And it is forecasted that the contribution on the GDP in Bangladesh will increase in the year 2025-2026.

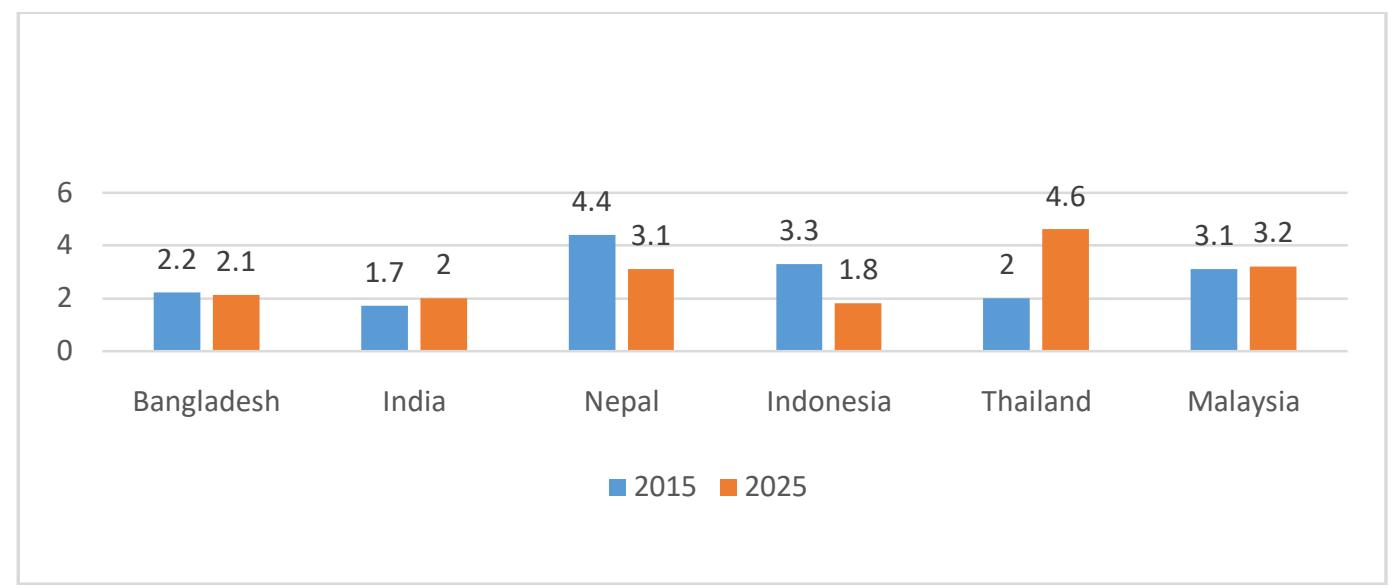

Figure 13: Total contribution of travel and tourism to employment (\%)

According to the above figure, the travel and tourism sector create more employment opportunities for Nepal among these countries in 2015. And it is forecasted that more employment opportunities will create in Thailand in the year 2025. In Bangladesh, the travel and tourism industry create relatively low employment opportunities for the people.

\section{SWOT AnAlysis of TOURISM Industry in BANGLADESH}

\begin{tabular}{|c|c|}
\hline Strengths & Weakness \\
\hline $\begin{array}{l}>\text { Blessed with a lots of natural, cultural, } \\
\text { archeological, historical, religious as well as } \\
\text { man-made resources } \\
>\text { Hospitable nature of people } \\
>\text { Longest sea-beach } \\
>\text { Largest mangrove forest } \\
>\text { Colorful culture and glorious history } \\
\text { Appealing foods and deserts }\end{array}$ & $\begin{array}{l}>\text { Poor participation of local community } \\
>\text { Insufficient funding } \\
>\text { Poor promotional activities } \\
>\text { Lack of safety and security } \\
>\text { Communication barrier } \\
>\text { Lack of awareness } \\
>\text { Less focus on new tourism policy making }\end{array}$ \\
\hline
\end{tabular}




\begin{tabular}{|ll|l|}
\hline \multicolumn{1}{|c|}{ Opportunities } & & \multicolumn{1}{|c|}{ Threats } \\
\hline$>$ Community based eco-tourism establishment & $>$ & Unawareness regarding sustainability of \\
$>$ Easy Promotion via social media & & destination \\
$>$ Research opportunity on tourism industry & $>$ Political instability \\
$>$ New types of tourism like dark tourism, floating & $>$ Absence of proper tourism policy \\
restaurant etc. introduction opportunity & $>$ Corruption \\
$>$ Innovation opportunity & $>$ Poor implementation of taking projects \\
\hline
\end{tabular}

\section{Recommendations}

Although there have been a lot of problems, the tourism industry is growing radically in Bangladesh. It not only impact on the economy of the country but also creates job opportunity for both male and female, ensures the conservation of resources; ensure proper utilization of all assets of the country. There are some recommendations, followed by which the tourism industry of Bangladesh can be one of the most influential sectors of the GDP growth.

$>$ Infrastructural and super-structural development needs to be carried out to the most visited tourist destination in the country.

$>$ Communication systems (Rail, Road, Air and waterway) need to be developed and properly maintained.

> Up dated tourism policies should develop and implement compared to the world tourism market.

$>$ Proper utilization of allocated budget on the civil aviation and tourism ministry should be ensured.

> Government and tourism planners should take action regarding the security system at the tourist police; more training should be offered to the tourist police.

$>$ Local community people need to be involved with tourism-related activities. Community-based ecotourism should flourish around the country.

> Public awareness should create among all locals, tourists, and persons who involved with tourismrelated activities.

$>$ More destination activities like surfing, scuba-diving, kidding, fishing, boating, art gallery, and facilities for at, gaming zone, children zone, etc. need to be created for attracting more local and foreign tourists.

$>$ Proper promotional activities (brochures, magazines, research on tourism, e-marketing activities, etc.) should be planned and implement around the world.

$>$ Both private and public sectors need to incorporate for the flourishment of tourism in Bangladesh.

$>$ Both male and female workers have to encourage and involve in tourism development in Bangladesh.

> Proper signage, poster and direction should be given in the tourist spots. Information Centre development for providing authentic information to tourists.
$>$ Distinct foreign zone creation for foreign tourists where they can enjoy the place more comfortably.

$>$ Tourist spots need to be calm, unbroken, as well as it should have fun, exciting, relaxing and educative.

> Bangladesh Tourism Board, Bangladesh Parjatan Corporation, and all other tourism scholars of Bangladesh, as well as all stakeholders, need to be incorporate in planning for ensuring better economic and other benefits from the tourism industry.

\section{Conclusion}

The direct economic impacts of tourism development are primarily measured in terms of visitor spending on accommodations, entertainment, attractions, food and beverage, and transportation, for both domestic and international travel. There are also, however, significant indirect and induced impacts that should be measured, resulting from the recirculation of that spending within local economies, and the jobs created and income generated by companies that supply the industry. The World Travel and Tourism Council estimate that the total impact of travel and tourism on global economic output will reach $\$ 9.2$ trillion by 2021. The direct contribution of Travel and Tourism to GDP reflects the 'internal' spending on Travel \& Tourism (total spending within a particular country on Travel \& Tourism by residents and non-residents for business and leisure purposes) as well as government 'individual' spending - spending by government on Travel \& Tourism services directly linked to visitors, such as cultural (like- museums) or recreational (like- national parks). The direct contribution of Travel \& Tourism to GDP is calculated to be consistent with the output, as expressed in National Accounting, of tourismcharacteristic sectors such as hotels, airlines, airports, travel agents, and leisure and recreation services that deal directly with tourists. This measure is consistent with the definition of Tourism GDP, specified in the 2008 Tourism Satellite Account: Recommended Methodological Framework (TSA: RMF 2008).

\section{References Références Referencias}

1. Ali, Mobasher (2004). Bangladesher Sandhanay, Student Ways, Dhaka, 3rd edition (Bangla).

2. Alex Delmonte, Articles named "Travel and Tourism Sector" published on academia, from the following 
linkhttps://www.academia.edu/10582286/Travel_and Tourism_Sector

3. Agndal, H. \& Elbe, J. (2007). The Internationalization Processes of Small and Medium-sized Swedish Tourism Firms. Scandinavian Journal of Hospitality and Tourism, 7(4), 301-327. doi.org/10.1080/15022250701640388.

4. Ashley, C. (2000), Working Paper: The Impact of Tourism on Rural Livelihoods, Namibia's Experience, Overseas Development Institute, UK.

5. P. Basu, (2004) Roots-Tourism as Return Movement Semantics and the Scottish Diaspora

6. Blanke and Cheisa (2007), the travel \&tourism competitiveness report.

7. Choi, H. C. and Sirakaya, E. (2005) Measuring Residents' Attitude toward Sustainable Tourism: Development of Sustainable Tourism Attitude Scale', Journal of Travel Research 43(4): 380-394.

8. Larry Dwyer, Peter Forsyth, John Madden \&Ray Spurr (2010), Economic Impacts of Inbound Tourism under Different Assumptions Regarding the Macro economy.

9. Elena, M., Lee, M. H., Suhartono, H., Hossein, I., Rahman, N. H. A., \& Bazilah, N. A. (2012). Fuzzy Series and Sarima Model for Forecasting Tourist Arrivals to Bali. Jurnal Teknologi, 57(1).

10. Faruk, Ahmed, and M. Hafiz Uddin Bhuiyan. 2003. Tourism in Bangladesh: The Problems and Potentials. Journal of Management Studies 8-9, no. 1 (June 2002-June 2003): 99-117

11. Goodwin, R. Santilli, Community-Based Tourism: a success? ICRT Occasional Paper 11, 1-37 (2009).

12. Hall, C.M. \& Boyd, S. (2005) 'Nature-based tourism and regional development in peripheral areas: Introduction.

13. Islam, Faridul and Islam, Nazrul (2006)."Tourism in Bangladesh: An Analysis of Foreign Tourist arrivals", http://stad.adu.edu.tr/TURKCE/makaleler/stadbah20 04/makale040103.asp

14. Jannatul Ferdous \& Hasan Mohammad Faisal (2014), Tourism potentiality and development of Bangladesh: applicability of pragmatic governmental management policy

15. Masud (2015) Tourism marketing in Bangladesh: what, why and how

16. Philip Pearce, G. Moscardo and G.F, Ross (1991), Tourism Impact and Community Perception: An Equity-Social Representational Perspective

17. Redwan, S. (2014) Tourism \& Socio-Economic Development: Focus on Bangladesh, a Destination Country

18. Shamsuddoha, Alamgir and Nasir (2011): Cultural tourism: Bangladesh Tribal areas perspective: Revista de turisms tudi is icercetari in turism, pages 28-32.
19. Sandip, S. (2014) Competitive Marketing Strategies for Tourism Industry in the Light of "Vision 2021" of Bangladesh.

20. Tosun, C. (2000). Limits to community participation in the tourism development process in developing countries, Tourism Management, vol. 21. 613-633

21. Sharpley, R. \& D. Telfer (eds), Tourism and development: Concepts and issues. 149-164. Channel View Publications, Clevedon.

22. Wall, G. and Mathieson, A. (2006). Tourism: Change, Impacts and Opportunities, Harlow: Pearson Education.

23. UNWTO Tourism Highlights 2008 and 2015

24. World Travel and Tourism Council (WTTC): Annual report- 2011 and 2014: The Economic Impact of Travel and Tourism 2014.

25. WTTC (2015), Economic impact of Travel and Tourism in the Mediterranean.

26. World Travel and Tourism Council, Travel and Tourism Economic Impact Report (2017).

27. Yilmez (2008), competitive advantage strategies for SMES in tourism sector. 